\title{
Myrosmodes nervosa (Orchidaceae, Cranichidinae, subgenus Myrosmodes): a new combination of Myrosmodes to Chile
}

\section{Myrosmodes nervosa (Orchidaceae, Cranichidinae, subgenus Myrosmodes): nueva combinación de Myrosmodes para Chile}

\author{
Patricio Novoa ${ }^{1 *}$, Carlos Vargas ${ }^{2} \&$ Mauricio A. Cisternas ${ }^{1,3}$ \\ 1Jardín Botánico Nacional, camino El Olivar 305, El Salto, Viña del Mar, Chile. \\ ${ }^{2}$ AECOM, Fourth Floor, 3292 Production Way, Burnaby, BC, Canada V5A 4R4 Vancouver, Canada. \\ ${ }^{3}$ Facultad de Ciencias Agronómicas y de los Alimentos. Pontificia Universidad Católica de Valparaíso. Casilla 4-D, \\ Quillota, Chile. \\ *pnovoa@jardin-botanico.cl
}

\section{RESUMEN}

De acuerdo a datos macromorfológicos y de hábitat se transfiere Altensteinia nervosa Kraenzl. al género Myrosmodes. Se describe la especie y se establece el tipo.

Aa and Myrosmodes were described by Reichenbach (1854) from material collected in Ecuador. Subsequently, the same author treated both genera as synonyms of Altensteinia (Reichenbach 1878), and during the following century all the species of Myrosmodes were included either in Altensteinia or Aa (Schlechter 1912). Later, Garay (1978) proposed that Myrosmodes was a distinctive genus from $\mathrm{Aa}$ and Altensteinia. Recently, Vargas (1998) and Trujillo \& Vargas (2011) have stressed that Myrosmodes has at least 6 morphological and ecological features unique to this genus: tubular lip with moniliform hairs, andromonoecious plants with male and hermaphrodite flowers of different sizes, basipetal inflorescence, accrecent peduncle, and habitat restriction to high andean/paramo and puna bogs dominated by species of Juncaceae. However, a molecular phylogenetic analysis conducted by Álvarez-Molina \& Cameron (2009) found that Myrosmodes is nested within Aa, although these authors suggested the need to sample more widely both genera to clarify the generic limits. As currently delimited, Myrosmodes includes approximately 12 species restricted to high elevations (3,800-4,600 m) in Andean South America (Pridgeon et al. 2003).

Vargas (1995) recognized two subgenera in Myrosmodes subgenus Rhynchocarpaea (Schltr.) C. Vargas, has a globuliform perianth, noticeably oblique insertion of ovary, recurved dorsal sepal and petals, ovary apex elongated into a variably long neck (i. e. rostrate), clawed lip with a cordate base and a wide ostium. On the other hand, subgenus Myrosmodes has a dorsiventrally flattened perianth, perianth insertion on ovary not oblique, apex of ovary not rostrate, erect dorsal sepal and petals, sessile lip with a cuneate base, and a narrow ostium.

Aa nervosa (Kraenzl.) Schltr., in the following referred to as Myrosmodes nervosa (Kraenzl.) Novoa, C. Vargas \& Cisternas (see taxonomy, later) shows the following characteristics of the genus Myrosmodes: a tubular lip with moniliform hairs (Fig. 1B, 2B), andromonoecious plants with male and hermaphrodite flowers of different sizes (Fig. 1A), basipetal inflorescence (Fig. 1C), and restriction to high andean bogs of Juncaceae (Oxychloe andina Phil.) (Fig. 1D).

Moreover, M. nervosa belongs in subgenus Myrosmodes because of the possession of straight, erect dorsal sepal and petals adnate to the back of the column, sessile, tubular lip without involute margins and with a cuneate base, perianth dorsiventrally flattened with its insertion on ovary not oblique, ovary apex not rostrate, and a narrow ostium (Fig 2A-C).

\section{TAXONOMY}

Myrosmodes nervosa (Kraenzl.) Novoa, C. Vargas \& Cisternas, comb. nov.

Basionym: Altensteinia nervosa Kraenzl., Bot. Jahrb. Syst. 36, Beibl. 80: 8. 1905. TYPE: CHILE; Taruguire, prov. Tarapacá. 3.756 m., 1904, R. Pohlmann s. n. (Lectotypus selected here, SGO 000001328!).

Synonym: Aa nervosa (Kraenzl.) Schltr., Repert. Spec. Nov. Regni Veg. 11: 150. 1912.

The protologue does not indicate the type specimen, only the type locality "nördliches Chile: Prov. Tarapaca bei Taraquire". We suspect that from three materials available in Global Plants Database (JSTOR) and with the annotation "Type", one is found at SGO (000001328), "Taruguire, Prov. Tarapacá" which 


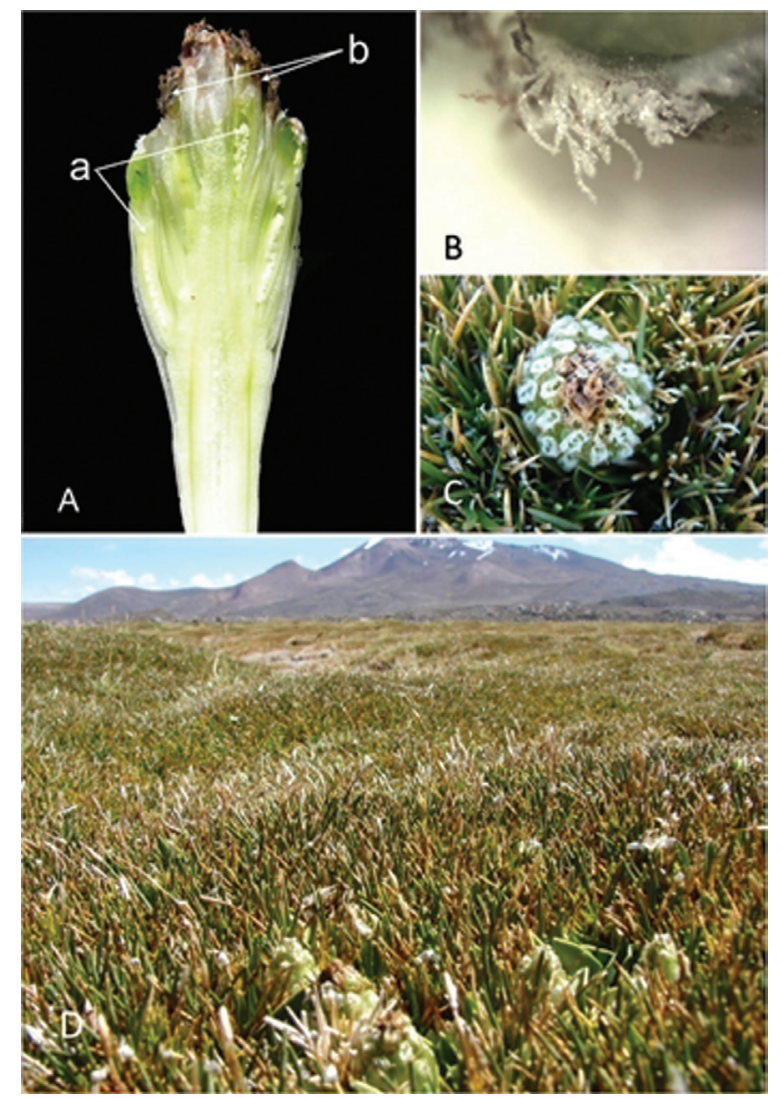

FIgURE 1. Myrosmodes nervosa. A: longitudinal section of inflorescence; a: hermaphrodite flowers, b: male flowers. B: moniliform hairs at the apex of the lip. C: details of basipetal inflorescence showing senescence of flowers. D: habitat of M. nervosa in a high andean bog of Oxychloe andina.

FIGURA 1. Myrosmodes nervosa. A: sección longitudinal de inflorescencia; a: flores hermafroditas, b: flores masculinas. B: pelos moniliformes en el ápice del labelo. C: detalle de la inflorescencia basípeta mostrando la senescencia de las flores. D: hábitat de M. nervosa en un bofedal alto andino de Oxychloe andina.

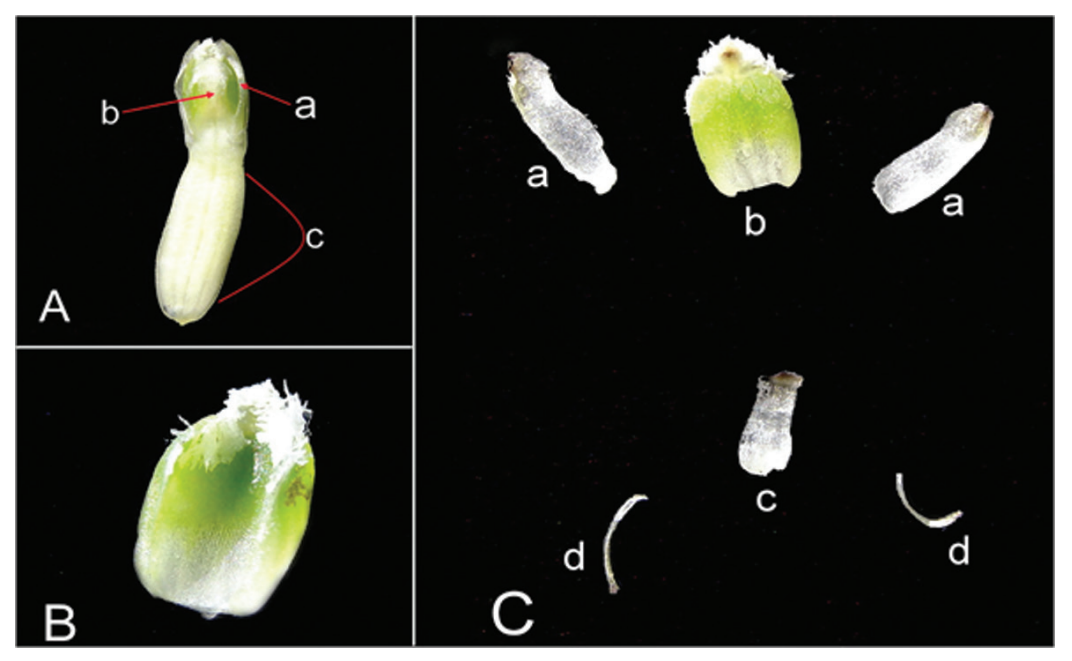

Figure 2. Myrosmodes nervosa. A: flower; a: petals, b: dorsal sepal, c: ovary. B: adaxial view of lip, with moniliform hairs at the apex. C: perianth parts, a: laterals sepals, b: lip, abaxial view, c: dorsal sepal, d: petals.

FiguRA 2. Myrosmodes nervosa. A: flor, a: pétalos, b: sépalo dorsal, c: ovario. B: vista adaxial del labelo, con pelos moniliformes en el ápice. C: partes del perianto, a: sépalos laterales, b: labelo vista abaxial, c: sépalo dorsal, d: pétalos. 
presents the most complete plants, and is in accordance with the protologue. Whereby, it is mentioned as "type" written by Kraenzlin. The remaining material cited as HBG 506651, HBG 506650 were excluded because of its ambiguous information.

Description: Plant with fleshy, fasciculate roots. Leaves forming a basal rosette, fleshy, spatulate with the apex acute, base petiolate, blades 1-3 $\times 1-2 \mathrm{~cm}$, whitish petiolate of 2-3.5 cm long $\times 3-5 \mathrm{~mm}$ wide. Inflorescence lateral and andromonoecious with short and accrescent peduncle, 8-12 $\mathrm{cm}$ long, covered by imbricating, hyaline, smal bracts. Floral bracts similar in length to the flowers but wider, covering them completely. Flowers non-resupinate with male flowers developing first at the apical part of the inflorescence and later hermaphroditic onest owards the base. Dorsal sepal deltoid-panduriform, rounded, $4.5 \mathrm{~mm}$ long, $1.4 \mathrm{~mm}$ wide at the middle, $1.9 \mathrm{~mm}$ at the base. Lateral sepals connate in their lower one-third, broadly linear and wider toward the apex, obtuse, $5.6 \times 1.8 \mathrm{~mm}$. Petals narrowly linear, slightly narrower at the middle, $4.4 \times 0.4 \mathrm{~mm}$. Lip broadly ovate, concave, greenish on the upper half and white-hyaline in the rest, $6 \times 4.3 \mathrm{~mm}$, its apex densely covered by moniliform hairs and with a triangular apical lobe $1.2 \mathrm{~mm}$ long.; disc of lip provided with dendritic veining and presence of obscure basal calli on the dorsal side of apex. Column light green, hyaline at edges, $3.4 \times 1.6 \mathrm{~mm}$., stigma rectangular, $1.5 \times 1.3$ $\mathrm{mm}$, almost half as long as the length of the column; rostellum shortly notched, brown. Pollinia four. Ovary $8.3 \times 3.4 \mathrm{~mm}$.

Additional specimens eXAmined: CHILE. Región de AricaParinacota, Prov. Parinacota, Vega de Parinacota. $4.400 \mathrm{~m}$ s.n.m. 19-V-1978. C. Villagrán, M. Kalin Arroyo, J. Armesto\& P. Uslar 1210 (CONC 53943); Parinacota, bofedales, al oeste de Laguna Cotacotani, 4424 m s.n.m. 23-III-2008. P. Novoa 238 (CONC 167126); Parinacota, bofedal frente al cementerio. 4400 m s.n.m. 23-VIII-2007. M. Rosas 5016 (CONC 169965). Región de Tarapacá, Prov. del Tamarugal, Bofedal de Sitani. 3730 m s.n.m. 21-III-1982. C. Villagrán \& M. Kalin 4197 (CONC 53830); Vegas de Villa Blanca. 3950 m s.n.m. 27-III1992. G. Arancio 90-448 (CONC 122179); Bofedal de los ríos Isluga y Sitari, entre Colchane e Isluga. 3700 m s.n.m. 7-8IX-1997. C. Villagrán, F. Hinojosa \& C. Latorre 9199 (CONC 142950). Región de Antofagasta, Prov. El Loa, Vega Aguada Choscha. 4150 m s.n.m. 10-X-1983. M.T.K. Arroyo \& C. Villagrán 831288 (CONC 117150).Región Tarapacá, Kränzlin 395 (HBG 506650); Región de Tarapacá, s/c, (HBG 506651).

Distribution AND ECOLOGICAL ASPECTS

M. nervosa grows associated with herbaceous cushion plants of Juncaceae, mainly Oxychloe andina, in Andean highlands from Arica and Parinacota to Antofagasta Regions, from 3,750 to $4,400 \mathrm{~m}$ elevation. This association, probably, is an evolutionary adaptation to endure the harsh environmental conditions in high-Andean bogs "bofedales" and "páramos" (Mytnik-Ejsmont et al. 2012). Their leaves and inflorescence are eaten by highland human habitants. Villagrán \& Castro (2004) recorded the following Quechua and Aymara compound root names: wakapsike, kolopsike, pukupsike, kolokolo, lokoloko, psikepsike.

\section{ACKNOWLEDGEMENTS}

The authors thank Gerardo Salazar and Amelia Chemisquy for providing valuable comments, and suggestions.

\section{REFERENCES}

Álvarez-Molina, A. \& K.M. CAmeron. 2009. Molecular phylogenetics of Prescottiinae s. 1. and their close allies (Orchidaceae, Cranichideae) inferred from plastid and nuclear ribosomal DNA sequences. American Journal of Botany 96: 1020-1040.

Garay, L.A. 1978. Orchidaceae. Cypripedioideae Orchidoideae Neottioideae. In: G. Harling \& B. Sparre (eds.), Flora of Ecuador, Vol. 9: 1-305. Swedish Natural Science Research Council, Stockholm.

Mytnik-Ejsmont, J., D. L. SzlachetKo, S. NowaK. 2012.Three new species of Myrosmodes (Orchidaceae, Spiranthoideae) from Colombia and Ecuador. Plant Systematics and Evolution 298: 1909-1916.

Pridgeon, A.M., P.J.Cribb, M.W. Chase \& F.N.Rasmussen. 2003. Genera Orchidacearum 3: Orchidoideaepart 2,Vanilloideae. Oxford UniversityPress, Oxford, $358 \mathrm{pp}$.

ReichenbaCh, H. G. 1854. Beiträge zur Kenntniss der Orchideen. Xenia Orchidaceae 1(1): 1-24.

Reichenbach, H. G. 1878. Orchideae Mandonianae. Xenia Orchidaceae 3:17-19.

SCHLEChteR, R. 1912. Die Orchidaceen-Gattungen Altensteinia H. B. et Kth. und $A a$ Rchb. f. u. Myrosmodes Rchb.f. Repertorium Species Novarum Regni Vegetabilis 11: 147-150.

Trujillo, D. \& C. Vargas. 2011. New species of $A a$ and new combinations in Myrosmodes (Orchidaceae: Cranichidinae) from Bolivia and Peru. Lankesteriana 11(1): 1-8.

VARGAS, C. 1995. New combinations in Myrosmodes Rchb.f. (Orchidaceae) Lindleyana 10: 5-6.

Vargas, C. 1998. Phylogenetic analysis of Cranichidinae and Prescottiinae (Orchidaceae), with some taxonomic changes in Prescottinnae. 152 pp. 20 figs. MSc. Thesis, University of Missouri, St. Louis.

Villagrán, C. \& V. Castro. 2004. Ciencia indígena de los Andes del norte de Chile. Programa interdisciplinario de estudios en Biodiversidad (PIEB). Universidad de Chile. Editorial Universitaria. 361 pp.

Recibido: 17.03 .14

Aceptado: 09.03.15 